Supplement of Geosci. Model Dev., 9, 323-361, 2016

http://www.geosci-model-dev.net/9/323/2016/

doi:10.5194/gmd-9-323-2016-supplement

(C) Author(s) 2016. CC Attribution 3.0 License.

(c) (1)

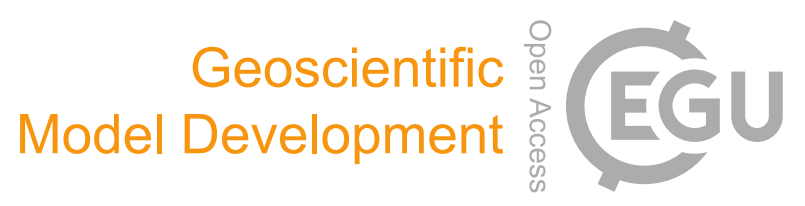

Supplement of

\title{
Competition between plant functional types in the Canadian Terrestrial Ecosystem Model (CTEM) v. 2.0
}

\author{
J. R. Melton and V. K. Arora \\ Correspondence to: J. R. Melton (joe.melton@canada.ca)
}

The copyright of individual parts of the supplement might differ from the CC-BY 3.0 licence. 


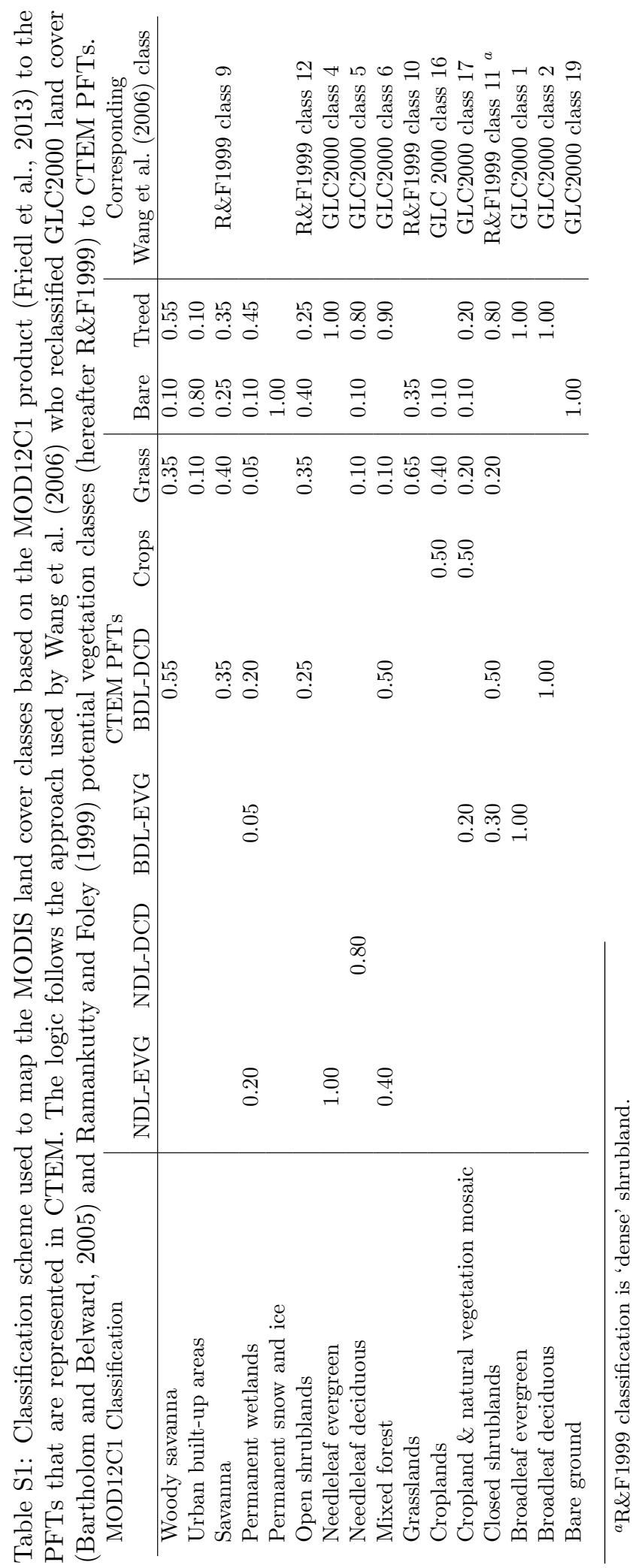




\section{References}

Bartholom, E. and Belward, A. S.: GLC2000: a new approach to global land cover mapping from Earth observation data, Int. J. Remote Sens., 26, 19591977, doi:10.1080/01431160412331291297, 2005.

Friedl, M., Strahler, A., Schaaf, C., Hodges, J. C. F., and Salomon, J.: Binary MODIS MOD12C1 0.25 Degree Land Cover Climate Modeler Grid, 2013.

Ramankutty, N. and Foley, J. A.: Estimating historical changes in global land cover: Croplands from 1700 to 1992, Global Biogeochem. Cycles, 1999.

Wang, A., Price, D. T., and Arora, V.: Estimating changes in global vegetation cover (18502100) for use in climate models, Global Biogeochem. Cycles, 20, doi:10.1029/2005GB002514, 2006. 